\section{St. Cuthbert, Lives of (Latin and $\mathrm{OE}$ )}

\author{
HELEN APPLETON \\ St. Hilda's College, University of Oxford
}

Cuthbert was a prominent Anglo-Saxon saint whose cult was patronized by the West Saxon royal house. A number of medieval treatments of Cuthbert's life survive in Latin and English, including Bede's Prose Life of Cuthbert, one of the most widely circulated lives of the period (Lapidge and Love 2001).

Cuthbert was born c. 635 in Northumbria. He became a monk at Melrose in 651, and spent time at Ripon before moving to Lindisfarne. Cuthbert's desire for the eremitic life led him to retreat to the island of Farne where he performed miracles and garnered considerable renown. In 685 he reluctantly agreed to become bishop of Lindisfarne. In 687, sensing death's approach, he returned to his ascetic life on Farne. Cuthbert died on March 20, and was buried on Lindisfarne. Cuthbert's community later fled Lindisfarne to escape Viking raids, taking Cuthbert's incorrupt body with them. Cuthbert rested at Chester-le-Street from 883, moving to Durham in 995.

The earliest account of Cuthbert's life and miracles is a Latin prose work composed c. 699-705 by an anonymous monk of Lindisfarne on the instructions of his bishop, Eadfrith (Colgrave 1940). The Anonymous Life of Cuthbert draws heavily on established hagiographic models. The text may have been intended for use within the Lindisfarne community as it contains a great deal of local detail.
Bede composed three versions of Cuthbert's life. Bede's Metrical Life of Cuthbert was produced in Latin hexameters c. 705, but revised at a later date (Lapidge 1989). The majority of surviving manuscripts commence with a dedication to a priest traveling to Rome. The preface depicts Cuthbert as a spiritual light to Britain, but does not indicate that the work was commissioned. The Metrical Life is a sizeable, challenging text, probably intended for individual contemplation; it depicts key events from Cuthbert's life without contextualization. Bede's Prose Life of Cuthbert was commissioned by Bishop Eadfrith of Lindisfarne and composed c. 720-22 (Stancliffe 2012). The Prose Life is influenced by the life of Benedict in Gregory the Great's Dialogues (Stancliffe 1989). Bede drew on the earlier lives, but the tone of the Prose Life is more homiletic. Bede added new information when he returned to Cuthbert in his Ecclesiastical History of the English People, completed c. 731. He devotes considerable space to Cuthbert, demonstrating his perception of Cuthbert's importance to the national narrative (Godden 1996).

Two Old English accounts of Cuthbert's life survive. The oldest is contained within the ninth-century Old English Martyrology (Rauer 2013). The entry for Cuthbert's feast on March 20 succinctly describes him as a holy bishop visited by angels, before recounting his transformation of water into wine. Ælfric of Eynsham included an Old English life of Cuthbert as Homily $\mathrm{X}$ in the second series of his Catholic Homilies, written within the period 990-95. Bede's Metrical Life was Ælfric's favored source, but he also employed the other early Latin lives (Godden 2000). The style of Ælfric's work reflects its homiletic 
purpose; miracle episodes are presented with little linking narrative and localizing detail is absent. The influence of the Benedictine Reform is evident; Cuthbert's time as a hermit is deemphasized, and greater prominence given to his role within the community.

A number of other histories, poems, and miracle collections concerning Cuthbert were produced in Latin and the vernacular during the medieval period (Bollandists 1898-1901; Hardy 1862-71). The best known of these later works are the Historia de Sancto Cuthberto (History of St. Cuthbert) and Symeon of Durham's Libellus de exordio atque procursu istius, hoc est dunhelmensis, ecclesie (Tract on the origins and progress of this the church of Durham). The Historia de Sancto Cuthberto was produced in the later Anglo-Saxon period and includes episodes not found in earlier lives (Johnson South 2002). The text transforms Cuthbert into a political force whose miracles affirm property rights. Symeon of Durham's early twelfth-century work includes Cuthbert's life and miracles as part of the history of his community (Rollason 2000). Symeon draws, often verbatim, on Bede's Prose Life, the Ecclesiastical History, and the Historia de Sancto Cuthberto.

SEE ALSO: Ælfric of Eynsham; Bede;

Hagiography; Lindisfarne; Martyrology, Old English

\section{REFERENCES}

Bollandists. 1898-1901. Bibliotheca Hagiographica Latina Antiquae et Mediae Aetatis. Brussels: Socii Bollandiani.

Colgrave, Bertram, ed. 1940. Two Lives of Saint Cuthbert: A Life by an Anonymous Monk of Lindisfarne and Bede's Prose Life. Cambridge: Cambridge University Press.

Godden, M.R. 1996. "Experiments in Genre: The Saints’ Lives in Ælfric’s Catholic Homilies." In Holy Men and Holy Women: Old English Prose Saints' Lives and Their Contexts, edited by Paul E. Szarmach, 261-87. Albany: State University of New York Press.
Godden, M.R. 2000. Elfric's Catholic Homilies: Introduction, Commentary and Glossary. Oxford: Oxford University Press.

Hardy, Thomas Duffus. 1862-71. Descriptive Catalogue of Materials Relating to the History of Great Britain and Ireland, to the End of the Reign of Henry VII. London: Longman, Green, Longman, and Roberts.

Johnson South, Ted, ed. 2002. Historia de Sancto Cuthberto: A History of Saint Cuthbert and a Record of His Partimony. Cambridge: Brewer.

Lapidge, Michael. 1989. "Bede's Metrical Vita S. Cuthberti." In St Cuthbert, His Cult and Community to AD 1200, edited by Gerald Bonner, David Rollason, and Clare Stancliffe, 77-94. Woodbridge: Boydell.

Lapidge, Michael, and R. Love. 2001."The Latin Hagiography of England and Wales (600-1550)." In Hagiographies: Histoire internationale de la littérature hagiographique Latine et vernaculaire en occident des origines à 1550/International History of the Latin and Vernacular Literature in the West from Its Origins to 1550, edited by Guy Philippart, 203-325. Turnhout: Brepols.

Rauer, Christine, ed. 2013. The Old English Martyrology: Edition, Translation and Commentary. Cambridge: Brewer.

Rollason, David, ed. 2000. Libellus de Exordio Atque Procursu Istius, Hoc Est Dunhelmensis, Ecclesie: Tract of the Origins and Progress of This the Church of Durham. Oxford: Clarendon Press.

Stancliffe, Clare. 1989. "Cuthbert and the Polarity between Pastor and Solitary." In St Cuthbert, His Cult and His Community to AD 1200, edited by Gerald Bonner, David Rollason, and Clare Stancliffe, 21 -44. Woodbridge: Boydell.

Stancliffe, Clare. 2012. "Disputed Episcopacy: Bede, Acca, and the Relationship between Stephen's Life of St Wilfrid and the Early Prose Lives of St Cuthbert." Anglo-Saxon England 41: 7-39. doi: 10.1017/S0263675112000099.

\section{FURTHER READING}

Colgrave, Bertram, and R.A.B. Mynors, eds. 1969. Bede's Ecclesiastical History of the English People. Oxford: Clarendon Press.

Godden, M.R. ed. 1979. Alfric's Catholic Homilies: The Second Series. Oxford: Oxford University Press. 
Gretsch, Mechthild. 2005. Alfric and the Cult of Saints in Late Anglo-Saxon England. Cambridge: Cambridge University Press.
Jaager, Werner, ed. 1935. Bedas Metrische Vita Sancti Cuthberti (Bede's Metrical Life of St. Cuthbert). Leipzig: Mayer and Müller. 
Please note that the abstract and keywords will not be included in the printed book, but are required for the online presentation of this book which will be published on Wiley's own online publishing platform.

If the abstract and keywords are not present below, please take this opportunity to add them now.

The abstract should be a short paragraph upto 200 words in length and keywords between 5 to 10 words.

\begin{abstract}
St. Cuthbert was a seventh-century bishop of Lindisfarne who spent time living as a hermit on the island of Farne. The cult of Cuthbert was very prominent in the Anglo-Saxon church and he was a popular subject for hagiography. Several lives of Cuthbert were written between the seventh and tenth centuries, in both Latin and Old English, including works by Bede and Ælfric of Eynsham. Texts concerned with Cuthbert continued to be produced throughout the medieval period, including verse lives, histories of his community, and accounts of post-mortem miracles.
\end{abstract}

\title{
KEYWORDS
}

500-999 CE; 1000 - 1099; 1100 - 1199; hagiography; Latin literature; medieval literature 